\title{
The Development Direction Analysis to the Newly Built Undergraduate College Under the Valuation Perspective
}

\author{
Li Xiaolong \\ Jiangxi Institute of Fashion Technology \\ Nanchang, Jiangxi \\ E-mail: 576816683@qq.com
}

\begin{abstract}
Under the popularization of higher education, the newly built undergraduate colleges are "booming", the number is growing gradually. Just as other types of undergraduate colleges, the newly built undergraduate colleges will accept the teaching evaluation organized by the ministry of education after the students had graduated for 3 years. The officials of the education department will inspects whether its school-running level is in line with the requirements. Giving the importance of evaluation index system, the development direction analysis of the newly built undergraduate colleges under the valuation perspective was been elaborated.
\end{abstract}

Keywords-Teaching Valuation; Newly Built Undergraduate College; Index System; Quality Guarantee

\section{INTRODUCTION}

For the implementation of the national medium and long-term education reform and development plan outline (2010-2020) ", to promote higher education quality guarantee system construction, and comprehensively improve the quality of higher education and talents cultivation, has the important guiding significance to the development of common colleges and universities, the ministry of education of undergraduate course of common colleges and universities teaching evaluation work opinion "(high [2011] 9), at this critical juncture formally launched.In this important documents, according to the actual situation, clearly put forward the "classification of colleges and universities. Colleges and universities evaluation including qualified evaluation and audit evaluation. Qualified evaluation object is not attended college since 2000 assessment of the newly built undergraduate course school; the review object is involved in ordinary undergraduate course colleges and universities evaluation and get through school."Assessment is in the stage of popularization of higher education the important measures to ensure the quality of undergraduate education and teaching in institutions of higher learning, is an important means of education administrative department of the transform function, is an important exploration of conform to the international trend of development of higher education. the newly built undergraduate course colleges and universities after has three university graduate will accept the ministry of education of the teaching evaluation, among them, the "qualified evaluation at school is the focus of the basic conditions for offering education, basic teaching management and teaching quality, school service ability of local economic and social development and the applied talents cultivation of ability, the school teaching reform and development of the internal quality assurance system and running situation. Assessment is a YingRenWu. Evaluation index system including seven categories, 20 events, 39 points, reflects the requirement for all aspects of the teaching about. Assessment conclusion is divided into" through ", "deferred by" and "not through" three."Through "five years into the review of school. In view of the higher education popularity time arrival, recently the number of newly built undergraduate course colleges and universities in our country is more, the higher education scale expands unceasingly, to clarify the train of thought, this article from the perspective of teaching evaluation of undergraduate course of common colleges and universities that do some analysis for newly built undergraduate course colleges and universities development.

\section{EXPLICIT THE RUNNING-SCHOOL THOUGHT, PAYING ATTENTION TO THE CHARACTERS DEVELOPMENT}

In the ministry of education of the undergraduate course of common colleges and universities teaching qualified evaluation indicators system, seven primary index system, index of the first class is the school-running ideas and leadership, under the cover school orientation, leadership and personnel training mode of three secondary indicators.Newly built undergraduate course colleges and universities, or the ordinary higher education covers the following three functions: personnel training, scientific research and social service, and inheriting culture, it has become a consensus.But when it comes to college orientation, is anyone guess, even some blind competition in colleges and universities, high level after (was eager to earn a bachelor's degree award authority to apply for master degree), and large scale (regardless of the actual conditions to establish new campus or set up a "commander"), subject as possible (like a hodgepodge, featureless), etc.The reason will appear these problems, the important reason is that their ideas are not clear, the school location is not accurate, or no well adhere to the correct education concept.University idea is the soul of a university, it is to guide the university to go on the power, is the essence of university.In the current new situation, either for a newly built undergraduate course colleges and universities or for a modern university, the most important thing is to have modern university school-running idea, its 
core is "people-oriented, pay attention to the academic, social service, reform and innovation."Talent training or training high-level talents is the basic task of higher education, the newly built undergraduate course colleges and universities should pay attention to students' different characteristics and individual differences, pay attention to their aptitude, insist on education, moral education first, ability, all-round development, actively carry out cooperative education.[2] trying to explore new mode of personnel training, constantly improve the quality of personnel training, improve service ability of society and the local economy development, win good reputation for themselves.As a government or other management department, to guide the new run by the local undergraduate colleges and universities to reform, inherent jump out of the public higher education ideas, to reform the survival and development, actively adapt to and meet the talent market demand for talents cultivation varieties, specifications, to foster social need, practical talents with qualified working ability.Newly built undergraduate course colleges and universities on the planning and development of the school, can never deviate from this core elements.In 2011 approved by the ministry of education for the undergraduate course colleges and universities of jiangxi institute of fashion technology can do better in this respect, in a timely manner after upgraded to undergraduate course colleges and universities put forward "have not formfitting, insisting not waver; accelerate not only speed, ascension is not stop".As for the leadership role in our socialist country, or affiliated provincial nature and some of the industry, the stronger of colleges and universities, introduced are the President responsibility system under the leadership of the communist party secretary, there needs to be referred to the point that colleges and universities should constantly towards with the center of teaching and academic development, can't let too much academic power, administrative power of colleges and universities should make great efforts to realize to the town, which under the existing system may be a long road, but should keep working in this direction, this will further enhance the service consciousness of colleges and universities, our university will constantly have new breakthrough.In addition, the undergraduate course of common colleges and universities teaching qualified evaluation index system for private, medical, arts colleges adjust some of the evaluation index of the notes, for private colleges to increase an observation point "" leadership system, the eligibility criteria as follows: the leading system, improve the corporate governance structure. The school board (or council), the reception committee, the members organization play their functions;Set up a school development and good decision-making consultation agencies play a role;Established the school teachers and students staff democratic management mechanism of supervision and make recommendations.[3] in recent years, private colleges develop very fast in our country, have sprung up, not only have a bachelor's degree awarding powers, some with master's degree award authority, three cent world play a role, but also made important contribution for China's popularization of higher education, private colleges should cherish the good development opportunity, contrast evaluation criteria, catching up and even beyond, make it become a flower in the Chinese higher education.

\section{STRENGTHEN THE TALENT ENROLLMENT, IMPROVE THE EDUCATION QUALITY}

In the ministry of education of the undergraduate course of common colleges and universities teaching qualified evaluation indicators system, seven primary index system, index system of the second is the teachers, the quantity and structure, education teaching level and index system of teacher training training three child.Due to historical reasons, Chinese private higher education running water And education level is relatively low, is mainly engaged in educational or non-curricula higher education professional type, occupation, "applied" is the basic characters of the mainland private colleges.[4] but since the reform and opening up, especially since the 1990 $\mathrm{s}$, private colleges in our country under the condition of the increase in the number and constantly improve the quality, and slowly run by the local undergraduate colleges and universities.As mentioned above, the basic task of the institutions of higher learning is to cultivate high-level talents, and talent cultivation and quality improve must rely on the teachers in colleges and universities, therefore, the newly built undergraduate course colleges and universities from accepting education organization of teaching evaluation, and starting from the fundamental purpose of higher education, should intensify their efforts to introduce talents and constantly improve the quality of education.Newly built undergraduate course colleges and universities are generally in the original form after the merge of a few schools, or in the original status of vocational college.Undergraduate schools and colleges have an obvious difference: is the undergraduate course school to cultivate the students' basic scientific research ability, it is made no specific requirements in the school.The scientific research ability show it from?In colleges and universities, the basic performance is to be engaged in scientific research, is engaged in the invention, has a certain ability to innovate.Therefore, in order to meet this need, the newly built undergraduate course colleges and universities should be based on the actual situation in the construction of the professional and curriculum, and related areas to be the leader, the curriculum should conform to the actual need, especially in the courses, to actively learn from the other brother institutions scriptures, modesty, the professional elective courses and public elective course this job as soon as possible.To introduce talents in quantity to meet the needs of teaching and on the structure of strewn at random have send, geographically to reasonable distribution, at degree level to a certain gradient.To increase the intensity of pre-service training for new talent introduction, let it set up the correct greatly under the condition of market economy, comfort for the sun the most glorious cause of education, to encourage teachers to actively participate in scientific research, scientific research level, improving school on ordinary post to create extraordinary brilliance, efforts to improve the quality of higher education, higher education power contribution for our country to enter their own talent. 


\section{REGULATE THE TEACHING MANAGEMENT, PERFECT THE SYSTEM CONSTRUCTION}

In the ministry of education of the undergraduate course of common colleges and universities teaching qualified evaluation indicators system, seven primary index system, index system of the sixth and the guidance of students is study style construction, establishing the index system for quality monitoring and style are involved in the system construction of institutions of higher learning.System is custom, the ancient words without a heart, no can be accomplished without norms or standards.In fact, the system involves every aspect of our university, teaching, management and the development of club activities, and even college teachers' professional ethics, and so on.In college, when it comes to system, we think of more modern university system: one is the macro level, the modern university system involves to the specification and straighten out the relationship between the university and government, universities and society;Second, micro level, the improvement of the university internal governance structure and reform.The former: moderate government macro management, market regulation, social participation, schools run independently according to law; The latter: party committee leadership, the principal responsibility, research professor, democratic management.Here to talk about the system is mainly the latter, because the communist party leadership, the principal is responsible for the evaluation index system of the first index system has been involved in, so now professor focus on research and democratic management of these two aspects. There is no doubt that should be centered on the teaching of colleges and universities, the academic professor should have the important say, academic power cannot be marginalized, if to be in this position, for our education, our country will be a very dangerous thing.However, in the strongly advocated to security administration in colleges and universities today, we must also avoid toward the other extreme, that is academic fraud, plagiarism the existence of cheating.We want to encourage teachers to actively participate in scientific research, but will never tolerate academic misconduct;We should value scientific research achievements, but must not be on the basis of the number, we call for scientific research and innovation, but certainly not manufactured.Otherwise, corruption is not only a professor of personal reputation and the reputation of the school, is also the holy hall of academic.And democratic management, democratic management research are closely linked with the professor actually, professor of research has been involved in the democratic management, the academic power and administrative power cannot be too much intervention even administration to provide all-round services for academic, both as to exactly how to distinguish the boundaries: ideally academic power held by professor, administrative power by administrative duties related personnel to exercise, but both should closely cooperate, communicate, so that is conducive to the development of the school good situation.Another very important aspect in the democratic management is to make staff have reaction channels of "public opinion", this is, of course, including teachers held regularly every year, many school democratic congress, but beyond that, but should also constantly improve the system, set up, including teachers and students appeal system (including network way), various conventional systems, in order to make the entire school teachers and students have reflected the staff channel.

\section{CONTINUOUSLY EXPAND THE CHANNELS, ENRICH THE CAMPUS CULTURE}

In the ministry of education of the undergraduate course of common colleges and universities teaching qualified evaluation indicators system, seven primary index system, index system of the sixth in the campus culture, college culture) is an important part of the monitoring points.Culture is an abstract name, but she is realistic society material carrier.University culture is the sublimation of knowledge, ability, personality and crystallization; Is the university ideology, system and a process of spiritual atmosphere;Also should be the spiritual home of idealists, is the university ideological enlightenment, combination of awakening and spiritual shock personality factors.Because of these characteristics, culture is the university does not immortal, let people mood is excited at the university, the university man craved.A university educational traditions and fine school spirit of the formation of style of study, to be accumulated in the long-term practice of running; The teaching quality and level of running a college and independent development ability, also need to be in the long-term exploration gradually in the process of ascension.[5] as a newly built undergraduate course colleges and universities, in addition to the normal daily teaching activities, also should make great efforts to carry out various forms, rich content of the second classroom activities, continue to expand students' knowledge, enrich students' inner life, cultivate the students' various learning interest.To carry out the second classroom activities can be the extension of the first class, such as all kinds of interest groups, debate, Seminar discussion, etc., can also be a play to their respective specialty societies, such as summer "a program under which officials" activities organized, usually in combination with the teaching of social survey and social practice, etc.Schools to carry out these activities should be organized carefully, carefully planning, would rather less, afterwards to timely summary, from experience, so as to create conditions to carry out similar activities later, continuously improve the level of events, and promote the students' quality.In the assessment, want to consider what is unique to the school, what is the advantage of the school, what can represent the school's teaching level, what can give inspection experts leave deep impression.For evaluation and assessment work is a systematic project.The essence of the evaluation is that it is just a form, if used well, it can maximize the low help us to know the school education teaching and the problems existing in the management work, to help us see clearly the direction of future development.On the surface, appraisal is in and review the past, but is, in fact, for the future, to find the direction of the school development.So the evaluation is constructive.To call for the entire school teachers and students from the perspective of constructive view of evaluation, to a normal heart to treat. 


\section{CONCLUSION}

In the 1930 s, American Taylor (r. w. Tyler) of "eight years" caused a worldwide movement education evaluation, foreign experience in this respect is more mature, and of higher education in China started relatively late.[6] above, combined with the teaching qualified evaluation index system of undergraduate course of common colleges and universities ", the newly built undergraduate course colleges and universities how to adapt to the new situation, analyzes some concrete from the aspects of the software, may not be complete or accurate, but when it comes to some of the problems or index system is newly built undergraduate course colleges and universities must face when evaluated and avoidance.Assessment of public universities and private colleges should be consistent, such as the training objective and specification;Others cannot importune consistent, such as the education resources, especially the evaluation of school funds, universities in state funding, can also charge fees, and no state funding private colleges, mainly by tuition revenue and some social support, and the evaluation criteria should be different of course.[7] of the People's Republic of China ministry of education once every five years the level of job of undergraduate course teaching evaluation is to test whether a school to realize education purpose, education task, the important way of implement education policy is the government, the society the important means of macroeconomic regulation and control of the school, especially in school education in the process of trial and error and the beacon to progress, all colleges and universities should contrast evaluation criteria, to find the gap, vigor, catch up, really achieve "to review construction, in order to review and promote change, promote tube through evaluation, evaluation of building" in the first place.

\section{REFERENCES}

[1] bing-lin zhong, hai-tao zhou, disappear, Wei Gong. Lessons learned research background trend innovation evaluation ideas - a new round of undergraduate teaching evaluation basic problem analysis (a) [J]. Journal of teaching evaluation in university, 2009 (1)

[2] of the ministry of education of undergraduate course of common colleges and universities teaching evaluation work opinion "(SongShenGao 2011.09.23)

[3] qiu-heng shi etc. China classification and assessment of the nongovernmental university $[\mathrm{J}]$. Journal of non-government education research, 2005 (2)

[4 bing-lin zhong, hai-tao zhou, Wei Gong, FanZhe, hai-tao zhou, Zhou Zuoyu. Stick to sorted guidance new classification standards of classification evaluation, a new round of undergraduate teaching evaluation basic problem analysis (2) [J]. Journal of teaching evaluation in university, 2009 (6)

[5] mei-ling liu, xu love. Foreign higher education evaluation system of private higher education assessment in China enlightenment [J]. Journal of hetao college, 2012 (12)

[6] Pan Mao yuan. Thinking about private universities evaluation and suggestion [J]. Journal of zhejiang ents university, 2008 (7)

[7] the higher education evaluation, the international experience and China - education evaluation branch of China's higher education institute in 2014 annual academic review, China's higher education evaluation, 1, 2015.

[8] tian-en shen, Richard Morris, the construction of internal quality assurance system of international comparison and construction framework, the education management of colleges and universities, 2015.01.Don't [9], a, newly built undergraduate course colleges and universities how to meet the job of undergraduate course teaching qualified evaluation, development and evaluation of higher education, 2014.11

[10] bing-lin zhong, the newly built undergraduate course colleges and universities should pay great attention to the connotation of development and the quality of construction, China's higher education research, 2015.06

[11] jin-xia liang, explore classification guide classification management approach, implement the autonomy of higher education, higher education research in China, 2014.10. 